\title{
Potential of palm oil-based agro-diesel in Butembo region in eastern Democratic Republic of Congo
}

\section{Summary}

Oil dependence is one of the major global energy problems exacerbating impoverishment in developing countries and especially in rural areas. This study aims to highlight the observation of this dependence for the Butembo region and envisages measures to reduce it by developing a potentially profitable sector, a hapax opportunity for the economic development of the peasantry. It deals with the use of a non-rare energy, palm oil as an alternative to diesel.

With this in mind, investigations have been conducted. They took us first to the customs institutions (DGDA) to raise the import share of diesel, then to facilities that have already experimented with palm oil as a fuel and finally to large consumers of diesel in the region (industrial, fuel pumping stations and other factories) to collect their opinions on agroenergy.

From the investigations carried out, it appears that in the Butembo region the import of diesel takes a heavy price annually which overlaps $40,000,000$ \$US for the last three years (2015-2017). The opinions of the respondents contribute to a consensus. They believe that palm oil-based agro-energy is a necessity in the region. However, this process requires technical, environmental and socio-economic prerequisites. At the technical level, the technological package must first be fully mastered and controlled to avoid the setbacks already experienced in the region. In terms of the environment, the extension of the palm grove to support agro-energy will have to be done with all caution, avoiding the generalized deforestation of forest massifs that are shrinking at the margins of the region. Similarly, this development will have to avoid producing the opposite effect of the expected results, which would consist in blocking the rise of the peasantry by large agricultural firms that crush the small family farming that is vital for the people in the study region. Well conducted, this process of adoption of agro-energy in the Butembo region can keep its promises. It raises many hopes, only preconditions remain the big challenges.
Volume 8 Issue 6 - 2021

\author{
Marjolaine Masika Mutani, Paul Katembo \\ Vikanza, Richard Katembo Kataliko, Galilée \\ Kambale Musavandalo \\ Faculty of Agronomic Sciences, Université Catholique du \\ Graben (UCG), Butembo, Democratic Republic of Congo
}

Correspondence: Richard Katembo Kataliko, Faculty of Agronomic Sciences, Catholic University of Graben (UCG), Butembo, Democratic Republic of Congo, Tel +243994528722, Email richardkataliko23@gmail.com

Received: November 01, 2021 | Published: December 07, 2021

\section{Introduction}

At the beginning of the 21 st century, global warming has become a proven fact that humanity must inevitably face. It is visible, according to the International Panel of Experts on Climate Change, ${ }^{1}$ in observations of the increase in global average temperatures of the atmosphere and ocean, in the widespread melting of snow and ice, and in the rise in global mean sea level. It is because of excess greenhouse gas (GHG) emissions, mainly due to human activities, that the natural greenhouse effect is unbalanced and the atmosphere is warming today more than necessary. ${ }^{2}$

This phenomenon is of great interest to scientists and the general public because of its implications for food security, health, the global and national economy and all other areas of life. Unfortunately, climate change is fundamentally unfair. The countries and populations that have contributed the least are the most threatened by its impacts and the least able to adapt to it. ${ }^{2}$ Africa is thus considered to be the continent that suffers the most from the effects of climate change. ${ }^{3}$

Among the GHGs, the most important, as recognized by the Kyoto Protocol, are carbon dioxide $\left(\mathrm{CO}_{2}\right.$ methane gas $\left(\mathrm{CH}_{4}\right.$ emitted mainly by the digestion of cattle and other ruminants), nitrous oxide $\left(\mathrm{N}_{2} \mathrm{O}\right.$, released by the soil which receives much more fertilizer than crops can absorb), fully halogenated hydrofluorocarbons, fluorinated hydrocarbons and sulphur hexafluoride. ${ }^{4}$ Currently, all these gases are seeing their concentration increase, but $_{\mathrm{CO} 2}$ is by far the most important, and therefore, the most involved in global warming. ${ }^{5}$ Among the major causes of the increase in its emissions into the atmosphere, we very often cite the strong industrialization, the change of use of forest areas in favor of agriculture, the combustion of fossil energy as well as hydrocarbons, deforestation and the degradation of large forest massifs. ${ }^{6}$

In addition, dependence on oil is an important part of the current energy problem. In the world's primary energy production, estimated at about 11.2 billion toe/year (tonnes of oil equivalent/year),oil is the most important source with $35.2 \%$ of the total. Gas and coal have weights of $25 \%$ and $21 \%$ respectively in 2008 (30.3\% in 2001). In 2004 , more than $80 \%$ of the world's energy production was still based on these 3 fossil fuels. If we add that nuclear electricity currently uses only the fission of Uranium-235, $87.4 \%$ of the world's primary energy production is based on non-renewable resources. The rest of the energy production, however, comes from renewable energies (woodenergy, hydroelectricity, wind, agro-fuels,...). ${ }^{7}$

The increase in ${ }_{\mathrm{CO} 2}$ emissions into the atmosphere is today one of the main global concerns as it can be read from the Kyoto Protocol. ${ }^{8}$

The governments of many countries have indeed decided to implement policies to limit these GHG emissions. ${ }^{5}$ The use of fossil fuels, which is the primary cause of the increase in the concentration 
of $\mathrm{CO} 2_{\mathrm{C} 2}$ in the atmosphere, ${ }^{9}$ by that of energy from biomass, should be an option to avoid the release of significant quantities of this gas into the atmosphere. Indeed, the net production of $\mathrm{CO}_{2}$ when consuming or burning biomass is very low due to its renewable nature. ${ }^{5}$

Thus, this concern about environmental problems, including climate change, has encouraged calls for the replacement of fossil fuels by «green» energy sources, including biofuels or better agrofuels. It was especially following the two oil shocks of the 1970s that the first attempts to produce this type of fuel took shape, particularly in Brazil and the United States. The surge in oil prices in the late 1990s also revived efforts in this direction. Several states have put in place measures to support the development of these organic fuels, which has led to an intensification of research and an increase in industrial production. ${ }^{10}$

Today, most agrofuels are used in automobiles and trucks. It can also be used in rail and air transport, although these jobs are less frequent..$^{10}$ It is known, in fact, that the transport sector alone occupies more than half (or 54\%) of the world's oil consumption, with the predominance of road transport, which occupies more than three quarters. ${ }^{11}$

In 2007, world production of agrofuels reached 62 billion litres, or about $1.8 \%$ of total world fuel consumption, a figure that is still derisive. As a result, a question arises: «Can agro-fuels be the alternative to fossil fuels, especially oil?» Obviously, agro-fuels are not necessarily the best alternative to oil, especially for the transport sector which is reputed to be the most fuel consuming in the world, but can advantageously be used elsewhere, especially in industrial facilities. ${ }^{9}$ In addition, they have the great advantage of coming from renewable resources, biomass, although the debate on the competitive use of their production space and that of human food remains intact. ${ }^{11}$ It is in this logic that this study is inscribed, which intends to explore the possibilities of developing agro-energy in a context where this new sector is still very little known and has hardly yet been tested.

\section{Environment, materials and methods}

The Butembo region, located between the parallels $0^{\circ} 58^{\prime}$ north latitude and $1^{\circ}$ south latitude and the meridian lines marked by $27^{\circ} 14^{\prime}$ and $29^{\circ} 58^{\prime}$ east longitude is formed by two territories of Beni and Lubero, in the east of the Democratic Republic of Congo. Itis an area where the production of agrofuels can generate interesting socio-economic and environmental benefits. Because of the dynamics that characterize this region inhabited by the Nande people,,$^{13}$ it is necessary to develop this new form of energy without witnessing setbacks, provided that the strategies implemented are in themselves thoughtful. It is above all an antagonism with the rise of small-scale subsistence family farming that must be feared the most. ${ }^{12}$

Subject to this reservation, the nascent industry in this region, particularly with the advent of the 'SIMBA'(BRASIMBA)and the industrial and commercial company VIUNGA (SICOVIR) in the territory of Beni, soap factories as well as many local wine factories throughout the region, can only constitute an opportunity to enhance this sector based on renewed energy. Ble. It should be noted that this young industry has greatly favoured the consumption of diesel, which has reached such levels that its tribute from the local economy is not negligible. It has been established an oil dependence of $37,300 \mathrm{~m}^{3} /$ year indiesel in the region. ${ }^{14}$

In this regard, another question is necessary; Could the region be spared the heavy toll imposed on it by the import of fossil fuels while guaranteeing its industrial development? It is here that agro-fuels find their insertion in the local economy. Well controlled, the latter can be a source of renewable energy to support the industry born in the region and therefore an alternative to diesel. The interest of the commitment in the sector is twofold. At the same time as diesel, this only polluting fuel, will be replaced by renewable energy, the development of agrofuel carries in itself an enormous potential for job creation in the region, one of the sure ways to restore the peasant economy as long as the contemporary world, at least more than that of yesterday, is made up of an energy-intensive company.

Both urban and rural areas are all concerned; in all sectors of activity, they owe their growth to energy consumption, for needs of both domestic and professional uses. Rural areas, in this case, will always have to rely on increased energy consumption for the mechanization of the agricultural sector. There is no need to demonstrate that the equipment of all this environment will require a sustained and regular supply of stable and reliable energy. Moreover, in the transport sector, for example, energy needs are growing by $1 \%$ per year. Demand for plastics, i.e. processed oil, used largely as packaging and manufacturing materials for industrial products, is growing by $3 \%$ per year. ${ }^{15}$

It is also the increase in the cost of oil in the long term, the geopolitical difficulties posed by its supply and its projected scarcity in the future that have led a number of consumer countries to study and implement a policy of reducing this dependence since the oil shocks of the 1970s. Today, the negative effects of oil consumption on the environment, particularly on global warming by the increase $\mathrm{in}_{\mathrm{CO} 2}$ emissions into the atmosphere, add to the disadvantages to accelerate the implementation of this policy. ${ }^{15}$

Al.D. Congo, despiteits announced or actual oil production potential, it depends almost entirely on external supplies for its oil supply. The question is whether the concern would have remained secondary to national priorities or whether it would have already triggered concrete policies to seek alternative solutions. Also, this country is full of so many other resources that can supplement, even a little, the oil consumption! This is the case, although still poorly controlled, of the agro-fuel sector.

More singularly, the question arises acutely in the region of Butembo, formed, in this regard, of the two administrative territories of Beni and Lubero. Here, as in the whole of DR Congo, access to electricity is a real headache for the population. The glaring lack of an adequate electricity grid and the very high cost of oil supply are an opportunity to undertake substantial research and investment in the region for other energies, particularly renewables, to serve it.

Mutani ${ }^{14}$ focused his investigation on the agro-energy potential of the region by taking the case of palm oil considered as an alternative to diesel. Item erged from this study that the import of diesel fuel costs the region about 40000000 SUS annually, huge incomes regularly taken from a population still living in economic precariousness. Then, the conditions identified as prerequisites for the development of the sector are technical, environmental and socio-economic. These include mastery of the technological package, caution in the extension of the palm grove, in order to avoid widespread deforestation in the region and the production of a responsible oil protecting the peasantry against possible agricultural firms that would crush, in this sector, small family farming.

On the basis of the results of the study carried out by Mutani,14 the present study aims to assess the possibilities of developing agro energy in the region of Butembo, estimates the potential level of 
production of responsible palm and finally develop a procedure for the local processing of palmoil into acceptable fuel.

\section{Results and interpretations \\ Possibility of development of agroenergy in the Butembo region}

\section{The import of diesel in the Butembo region}

The data collected at the Directorate-General for Customs and Assizes (DGDA/Kasindi) provide information on the quantities of diesel imported into the region studied via the Kasindi-Lubiriha border crossing. The total quantity imported for three years (from 2015 to 2017) was $115,718,664$ litres, for an annual average of $38,572,888$ litres of diesel. The statistics obviously do not give the full amount used in the region, especially since other imports, fortunately minor, arrive in the region through the mahagi or Bunagana regions.

Considering the price of one dollar per litre at the pump, the cost of importing is estimated at about US $\$ 38,572,888$. From this graph, it is to be noted a difference in imports between the first two years considered (2015 and 2016) which have an average of around 42,000,000 liters and the last (2017), with a low import, found around 32,000,000 liters. This drop in imports, estimated at about ten thousand $^{\mathrm{m} 3}$ of diesel, can be explained in part by the use of other types of energy by some large consumers identified in the region. This is precisely the case with SICOVIR's facilities in Mutwanga, which has oriented some of its equipment towards the consumption of energy produced by a hydroelectric power plant.

\section{The consumption share of large users}

The consumption of diesel is divided between large and small users. Small consumers are those who source at the pump for often intermittent uses; not concerned by this study, especially since the limited quantities they consume do not justify the conversion to agrodiesel. Porr the major users considered, the consumption of diesel is high because they use day and night of the large motors of the generators and continuously. This group of consumers is interested in agro-diesel because of the high volume of their uses and the costs involved, which can support the development of the palm oil-fuel sector.

Diversification in the use of diesel is felt even among large users subdivided into three classes: the largest (especially industrialists), the large (formed by wine factories and soap factories) and he means (which are the pumping stations of fuels).

Overall, the monthly consumption of the three groups amounts to 1433805 litres divided into 1391915 litres (97\%) for industrialists who are the largest users, 28450 litres (2\%) for local factories and 13 440 litres for pumping stations (1\%). On deduces that the quantity of diesel consumed annually by large users is 17205660 litres surveyed, which represents about $45 \%$ of the total consumption of the region.

In addition, by reconsidering the cases of non-response encountered in the field and the possible omissions of potential users of agrodiesel, this percentage can be revised upwards. Hence we consider that it is appropriate to bet on $50 \%$ of the total consumption of diesel in the region that can be diverted towards the development of the palm oil sector; which represents a hefty sum of 20,000,000 \$US per year to be donated to the palm grove. This constitutes an important economic part for the peasantry.

\section{Known cases of palm oil combustion in the region}

Having noted from the pre-investigations that the Moto radio station in Butembo tried to experiment with palm oil as a fuel, we wanted to understand the situation further. The managers of this station have attested to the fact and have told us two other colleague stations that have the same experience: the radio stations Muungano de Beni and Moto d'Oïcha. The investigations first indicated the case of the two Moto radio stations (RMBB) that have almost abandoned the adventure of agro-diesel while the trial is still ongoing of the Radio Station Muungano de Beni (RMB) which uses a LISTER brand generator.

From the managers of these stations, we learned that it was the Radio France Internationale (RFI) Planète Radio which had launched, since 2012, the offer of generators well adapted to the use of palm oil at all its relay stations throughout the tropical world. Radio Moto Butembo Beni (RMBB) was among the beneficiaries for its two stations in Butembo and Oïcha. They are not the only institutions in the DRC that have benefited from the project. In the former Orientale province, the Nava radio stations in Isiro, Boboto in Yangambi and Rubi in Buta; in the former Bas-Congo province, the Nzola Kanda radios in Mbata Mbenga and Ntomosono in Luozi; in the former province of Bandundu Madimba in Gungu and Nsemo in Idiofa.

Initially, the experiment seemed to be too conclusive at the RMBB. The operation of the machine has been flawless tothe point that its use has allowed a high profitability in the extreme, facilitated by the high availability of palm oiland especially the relatively low price of this local product. However, this only held the cost for about 12 months. Over time, the mechanism quickly showed its limitations, which were due in particular to the weak technical equipment of the RMBB. The disadvantages of the device pushed the RMBB to abandon, momentarily, this adventure. Indeed, palm oil, as collected raw from farmers, has a high viscosity that requires too much cooking time until the turning point of the oil, vulgarly called "k ambili or Mafuta ya kambili", where it becomes more fluid than in the normal state. Only in this state can it be used in the generator. Locally, the RMBB has used firewood for this prior cooking; which already contributes, as well, to air pollution. Then, once the generator is shut down, the oil cools to a very short time and clogs the fuel pipes itself. It therefore requires non-stop operation of the engine. Also the use of palm oil does not completely eliminate that of diesel. At start-up as before shutdown, the mechanism requires that the device be activated by using the diesel feed route for about 5 to 10 minutes to avoid clogging of the cooled palm oil.

To these whims related to the operation of the machine are added inadequacies specific to the institution. There is blame for the scarcity of engine spare parts, the inaccessibility to the "chemicals" used to test palm oil before use. In this regard, it is curious to note that this ingredient is not known otherwise by the interlocutors; they limit themselves to talking about "chemicals" without giving either the name, the characteristics, or even the origin. They receive these products from RFI Planète Radio, which reflects the vulnerability of such a mode of dependence. There are also the problems of the general economic situation in the environment. In difficult times, the supply of oil is made difficult by obstacles related to the dilapidated state of the service roads and the physical insecurity perpetrated in the production environment.

Contrary to the stopped experiment of the RMBB, the RMB continues to use this technology inherited from the RFI Planète 
Radio. Its test in agro-diesel is so far conclusive for reasons of precautions mentioned by the interlocutors. At the RMB oil supply, they have always taken great care to observe the instructions received when acquiring the equipment. The oil, before use in the engine, must always go through certain stages. The oil must first be tested by "chemicals", already mentioned in the case of rmbb, in order to decide on its validity. Using asyringe, $5 \mathrm{ml}$ of the "chemical" is taken and mixed with $15 \mathrm{ml}$ of the oil sample to be tested and the mixture is left to rest in a jar. After 5 minutes, the color of the mixture should turn from orange (the natural color of the oil) to a light shade like water. Observed for another 5 minutes, if the orange color of the oil does not return, then the product is to be downgraded, it is declared unfit for use in the generator. On the other hand, the oil to be selected will be characterized by the second turn, after 10 minutes in total, from the light tint to the initial color of the oil.

There tained oil is subjected to prior cooking to considerably reduce its viscosity to make it more fluid; here too wood is used. As a result, the fluid oil passes through a series of three filters to remove impurities before being driven to the generator tank while ensuring the precautionary measure already signaled at start-up and stop: operate the device, for 5 to 10 minutes, with diesel.

This type of generator therefore uses two tanks with two types of supply, oil and diesel. Figure 1 gives an idea.

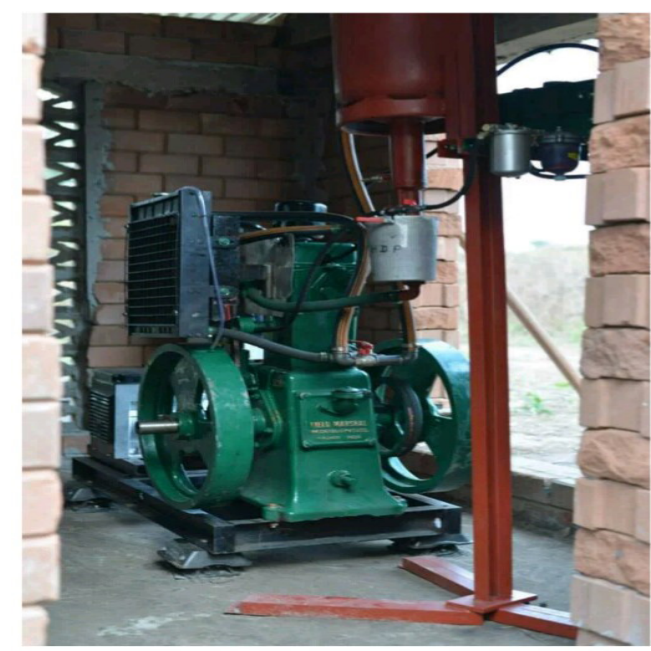

Figure I Image of the generator using palm oil at RMB.

For RMB managers, the use of this generator has great advantages. First of all, the fuel used is not rare and does not cost much; in addition, its fuel efficiency is much better, in terms of cost incurred, compared to diesel. According to the head of the RMB technical service, the hourly consumption of the generator does not differ for the two fuels ( $0.48 \mathrm{l} / \mathrm{h}$ for palm oil and $0.50 \mathrm{l} / \mathrm{h}$ for diesel), but the price per litre differs considerably, it is 0.25 \$US for vegetable oiland1 \$US for diesel. For him, by using palm oil instead of diesel, we earn four times more.

\section{Trends in the face of agro-diesel}

Energy security, as indeed in many corners of the world, ${ }^{16}$ is now a major concern in the Butembo region. This is what is reflected in the comments collected from our interlocutors, the major consumers of diesel met. Speculation around this security has often always been associated, directly or indirectly, with economic, social and political instabilities.

For all our respondents, apart from a few supporters of fuel pumping stations, theuse of renewable resources as an alternative to oil (fossil resource) is an aspect of sustainable development in our environment. This development will take into account nature as a supplier of the raw material, the technology of production and processing of palm oil. The use of this oil must also learn a lot from the experience of those who already know about agrofuel.

They consider, moreover, that the use of agricultural products for energy production may be full of disadvantages such as the unavailability of the product, which would be exacerbated by competition between human consumption and that of generators. Other problems mentioned are the difficulties of access to the production areas with the state of the roads in disrepair and the technical limits such as the non-control of the viscosity of the palm oil which can lead to damage to the equipment, the tools necessary for the proper functioning of the device, the pre-treatment of the oil as its refining, etc.

The obstacles to agrofuels as an alternative to oil are not only in the availability of the resource already produced but also in the increase in its production. The existence of appropriate policies is fundamental to ensuring the efficient sustainable and economically viable development of these renewable resources.

For the production of agro energy and its development in the Butembo region it requires a large area of land to be cultivated so as not to harm food production, the ecosystem and biodiversity (forest, soil, water, etc.)

As a result, agro-energy can indeed contribute to increasing energy supply in the region, with positive effects on the price, availability and universal access to energy on many levels if precautions are taken before its development. And this can reduce oil dependence and induce economic and industrial development of the region.

\section{The future of the agro-fuel sector in the region}

In dealing with the prospects of agro-diesel in the Butembo region, the elements noted here come mainly from the company Enzyme Raffinée "ENRA". His point was in fact one of the great lessons learned during our investigations.

We agree with him that agrofuels are not a one-dimensional energy option. They can be accompanied by sustainable development, job creation, reduction of greenhouse gas emissions and increased access to energy.

This biofuel in the Butembo region will allow an evolution in various fields: energy, social, environmental, agricultural, economic and technological. The expansion of agrofuel based on palm oil will not lead to deforestation or land degradation if environmental protection policies are implemented. The delimitation of agricultural areas is a means of avoiding deforestation and the displacement of agricultural activities to areas of natural vegetation. Similarly, we agree with the respondents that biofuel is not a universal remedy. It is important to recognize that the heavy energy debt is one of the main causes of the image of underdevelopment in our countries or better of the Butembo region despite our potential in raw materials.

The best way to achieve a balance between the potential benefits and risks of agrofuels is to establish scientific sustainability criteria because the current moment represents an opportunity for these agrofuels to be the ones that drive the new cycle of rural development.

Any initiative always has advantages and disadvantages. For this study it was considered that the main thing is to maximize the positive sides and mitigate the negative sides. It is in this way that we are poor that we will be able to enjoy an effectively sustainable development to face the very rapid growth of demography. 


\section{Estimation of the potential level of responsible palm oil production}

\section{The current state of oil palm cultivation in the Butembo region}

Just a visual overview, even the most basic, of the landscapes of the oil palm ecological zones in the region is enough to get an idea of the general a spect of the palm groves that remain to us. The observation is clear: we see a mosaic of shrub plant formations dotted with the feet of relatively rare palm trees; old wild or natural plantations! On all three axes visited, whether on the side of Manguredjipa, BingoMabalako or Mbau-Oïcha, the impression remains the same: the exploitation of oil palm in the region is done by picking.

This bleak picture corroborates the postulates put forward at the Kinshasa workshops, held from 28 to 29 October 2015, on green growth in the palm oil sector. Here, it has been claimed, for the whole of DR Congo, that many of the spaces once allocated to this culture have been vast abandoned fallows for more than 30 years. Most of the plantations date from the colonial era and the average age of their unexploitation is 40 years, since the Zairianization (of 1973). As a result, industrial exploitation has already been abandoned in favor of production by picking palm oil. The old plantations, once regular, have given way to other uses. Today they give secondary forests, food crops and fallow land in which are scattered, here and there, old palm feet visibly orphaned by their former protectors. ${ }^{17}$

Indeed, by addressing the issue with our respondents, our impression is confirmed. On the other hand, we have not encountered any nurseries. The young shoots of palm trees that can be encountered in these environments are spontaneously found; which deserves the qualification of wild palm groves! The natural location of the latter therefore does not follow any standard as to the spacings; the manure being then completely unknown and the varieties that settle remaining totally uncontrolled. However, when a wall diet appears, the palm tree seems to suit everyone, the income it provides obliges it. If necessary, our respondents know how to distinguish, at harvest, the Dura variety (locally called "Nyabu"), with poor yield, from Tenera varieties (locally called "Wamba" and "Canada"), with much more acceptable yields. The picturesque state of this wild palm grove is better glossed on Figure 2.

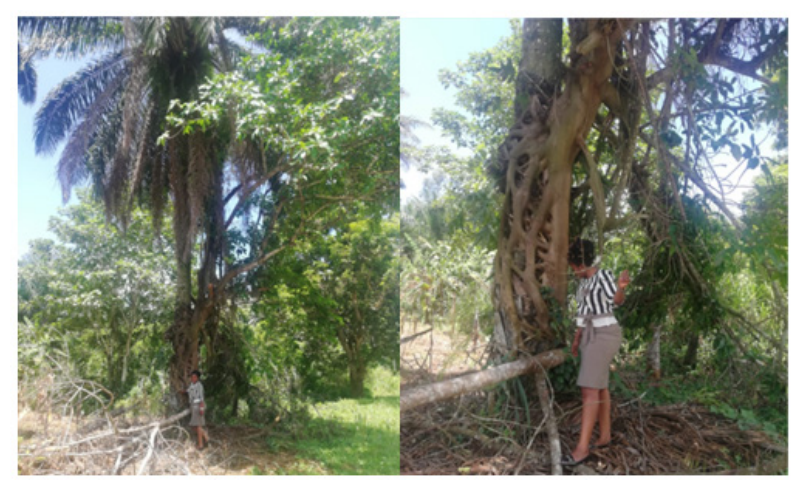

Figure 2 Ficus invaded abandoned palm trees as epiphytes.

\section{Spaces available in the face of the concept of responsible palm oil (HPR)}

In response to criticism of the oil palm industry, a multi-stakeholder organization, the Roundtable on Sustainable Palm Oil (RSPO), was created in 2004. It is intended to promote the production, marketing and use of an oil according to standards ensuring the robustness and balance of the pillars of sustainable development. This is the meaning of the concept of Responsible Palm Oil (HPR). ${ }^{16}$

Potentially, DR Congo is a global palm oil power. It has therefore taken its alignment in favour of the HPR. In the Kinshasa workshops, mentioned above, members of the RSPO (OXFAM-NOVIB, CACUDEKI, etc.) affirm that the revival, through the villages, of modern palm groves is offered as a possible solution in the context of poverty in the DR Congo. They add that the exploitation of palm oil in post-conflict areas such as Lubero, Beni, etc. offers opportunities to provide clean energy, structure agricultural producers around the sector and develop an integrated local industry in the sector.

In this regard, the intentions of the RSPO are broken down into national principles formulated and proposed on occasion for the development of Responsible Palm Oil (HPR). Oil palm cultivation sets itself the goal of zero deforestation; in its policy, it promotes the interests, opportunities and livelihoods of small producers. Investments in this sector are then aligned in a win-win partnership between companies (public and private) and local and indigenous communities; the development of the HPR value chain is based on research results and innovations relevant to DR Congo.

Based on these principles, surveys conducted in oil palm landscapes in the Butembo region reveal that the majority of respondents have little concern about the issue of deforestation. $80 \%$ of the respondents believe that if the means allowed, they would transform into palm groves the few forest areas that remain in their environments and which are also doomed to disappear by the felling of timber by the wealthy.

It was also noted that almost all respondents fear the advent of large agricultural companies, such as the Agro-Industrial Park of BukangaLonzo. The fear is that such an initiative will take over agricultural land, which has become increasingly scarce, to the detriment of small producers who are becoming landless peasants; All the respondents, then without exception in sector of Bapere, on the axis BiambweNjiapanda-Zacharia-Manguredjipa, recognize the oil palm as "their life". Even without land, every peasant has at least palm trees that he exploits. It is then recognized, in this environment, a particular right on palm seedlings that a farmer can buy for the exploitation of his oil without as much control the soil that shelters them. The price of a young palm tree close to production is trading on average around US\$ 5 .

The respondents nevertheless recognize that the palm tree cannot replace all the other crops, especially food crops, that provide food for the population. It is therefore a question of finding a compromise between the establishment of the palm grove, as a leader in local farming systems, the space reserved for food crops and other cash crops without minimizing the place of the forest in this tropical environment. Based on these field data, we considered that environmentally friendly land use planning on these palm landscapes could be based, in a global way, on the following proportions of land use: $1 / 3$ land reserved for forests (natural or reforestation); $1 / 3$ land reserved for the palm grove, and land reserved for other $1 / 3$ crops. With this distribution, projections of the areas to be allocated to the controlled and improved cultivation of oil palm are then made possible. If the data provided by the administrative maps of two erritories of Beni and Lubero are agreed, they show an ecological zone suitable for palm cultivation which covers the $2 / 3$ Butembo region asa whole, as shown in Figure 3.

From this consideration, knowing the respective areas of the beni $\left(7484 \mathrm{~km}^{2}\right)$ and Lubero $\left(17095 \mathrm{~km}^{2}\right)$ areas, we grant the Butembo 
region a total area of $24579 \mathrm{~km}^{2}$ of which $2 / 3$, i.e. $16386 \mathrm{~km}^{2}$ constitute the area suitable for the cultivation of oil palm. Considering the proportions taken for the development of these landscapes, palm groves can be established on $1 / 3$ either $5,462 \mathrm{~km}^{2}$ (or $5,500 \mathrm{~km}^{2}$ environ). Projections for available surfaces logically pave the way for estimates of the quantities of oil that can be produced in the region. Of all oilseed plants, it is recognized that it is the oil palm that provides the most yield. ${ }^{18}$ This author mentions a fruit yield of more than 9.3 tons/ha/year and years in the humid regions of West Africa this yield is estimated at about 4.5 tons/ha/year. ${ }^{18}$

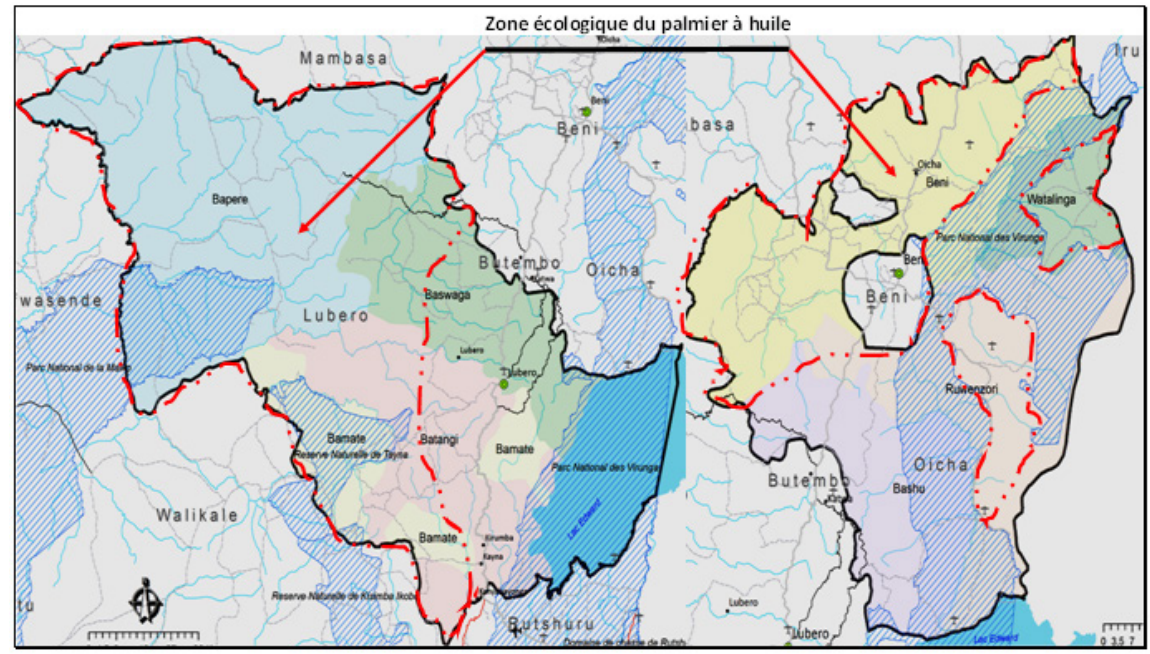

Figure 3 Oil Palm Ecological Zone in Lubero Territories (left) and Beni (right).

Source: https://reliefweb.int/sites/reliefweb.int/files/resources/-ocha_drcNKivu03 I I03.pdf.

For its part, the Center for International Cooperation in Agricultural Research for Development ${ }^{19}$ informs us that the average global productivity of palm oil is 3.8 tons / ha / year, of the order of $6 \mathrm{t} /$ ha / year in good agro-ecological conditions. In our case of the Butembo region where, according to the picture painted of the current state of cultivation, everything remains to be redone, it seems logical to us to take moderate figures for the yields to be considered in our projections, i.e. a value of 3 tonnes/ha/year. This gives, for the projected ecological zone $\left(5,500 \mathrm{~km}^{2}=550,000 \mathrm{ha}\right)$ :

550000 ha $\times$ tonnes / ha / an $=1650000$ tonnes $d$ ' huile de palme / an

Considering the density of palm oil $(\rho H p)$ estimated at 0,92 tonnes $/ \mathrm{m}^{3}$, this potential mass of oil represents a volume of $1793478 \mathrm{~m}^{3} \mathrm{~d}^{\prime}$ 'huile de palme / an, or approximately $1800000 d$ ' huile de palme / an. This is far higher than the region's diesel imports which have been estimated at around $40000 \mathrm{~m}^{3}$. Hence, we believe that these potential productions can fully cover both the food needs of palm oil in the Butembo region and its demands for diesel fuels.

\section{Local processing of palm oil into acceptable fuel}

\section{Palm fruit machining in the region}

In the Butembo region, the difficulties of palm groves are not only located at the level of the conduct of cultivation in the field. They are also present at the stage of the transformation of palm diets into oil. Among our respondents, what they call palm oil "factories" are in reality small rudimentary facilities for artisanal palm oil extraction. Commonly, they are found under small makeshift sheds or sometimes in the open air without any roof. It is here that users come with their batches of palm seeds from the meagre diets produced from the pick, already softened and destemmed in the field.
By the way, the very rudimentary equipment, just a manual or often mechanical mixer without any pressure, does not allow to obtain significant yields at extraction. For these respondents, to try to extract the most oil from the palm seed, they adopted everywhere the same procedure of palm oil processing. It consists of harvesting the palm diets, then piling them up in the field, covering them with the leaves and letting them ferment and soften for about a week until, on destemming, the seeds easily detach from the diet, by hand or by simple blows of a stick. The seeds separated from the rachis are then transported, on the backs of the women, to the extraction facilities.

At the machine shop, the first operation is the cooking of the seeds in barrels for one to two hours to prepare them for extraction. Once cooked, the seeds are transferred, all hot, into the mixer to extract the oil. While the arms of the mixer, carried by a central axis, beat and crush the seeds against the walls of a barrel perforated in its basal part and which constitutes the extractor, the pulp of the seeds releases its oil content which oozes through the perforated orifices on the extractor. This oil constitutes what the peasants call "first quality"; it is collected in vases. Then, when the oil no longer oozes on its own, water is gradually added to the crushed mass to harvest the remaining oil still contained in the fiber-palm nut mixture remaining in the extractor. This oiled water is sent to wooden tanks where the oil is skimmed above the water. The last operation consists of a clarification of the oil brought to a boil in barrels in the open air: water and coarse impurities precipitate and the oil is recovered, by simple skimming, by means of the shallow containers.

In addition to the visibly poor yield of this necessarily elementary process, its major disadvantage is reflected in the quality of the oil that comes out inexorably affected. The seeds fermented before processing had time to release the GLA during their extended stay in the field after harvesting the diets. By the way, the goal of palm oil processing doesn't just stop at extracting as much oil as possible. It is also a question of ensuring the quality of the product, a palm 
oil that can be easily stored. These requirements depend on the GLA content, the soiling of the oil with water and other impurities and the discoloration qualities. The presence of water and other foreign contaminants strongly promotes the formation of GLA through the activity of lipolytick enzymesor lipases. ${ }^{18}$

Indeed, the formation of GLA in palm oil may be due to autocatalytic action, enzymatic lipase from palm fruit, or microbial lipases. Fatty acids appear mainly as a result of the action of lipase before treatment. Palm fruits contain active lipase, the action of which causes fat to break down into fatty acids and glycerol when the fruit cells have been damaged. The membranes of the vacuoles, which can be broken mechanically or by the cold, protect the fat from the lipase in the fruit. The enzyme is completely inactivated at temperatures above $55^{\circ} \mathrm{C}$. Thus, to produce an oil low in GLA, it is imperative to avoid any breakage of the fruits. The purpose of sterilization, apart from facilitating the destemming of fruits and disinfecting them, is to inhibit the action of lipolytic enzymes, thus avoiding the formation of GLA. ${ }^{19}$

As a result, the oil produced by the farmers, after fermentation of the seeds, is not adapted to our operations of use in the engine where we are particularly afraid of the corrosion of the exposed organs. Obviously, we were already warned, the remark had been given to us during our investigations among the mechanics of the garage "Munyangulo" which has some experience in the use of agro-diesels. That is why, for our test, we opted for the extraction, by ourselves, of the oil that constituted our experimental material, following the process described in the methods section of this work..$^{20-47}$

Also, it is curious to note that for our respondents, there is no question of changing technique. As already mentioned in the method part of this work, many of these women refused to provide us with fresh diets for our experimentation. They do indeed criticise the extraction procedure used by the test, which they describe in the local dialect as 'Erikarambura' or forcing, for not releasing the oil contained in the pulp. This can only be justified in view of the poor capacity of the locally available extractors.

\section{The physico-chemical properties observed}

In our tests, five elements were analyzed in the laboratory. First the acid number (Table 1), it made it possible to find the basics of oil refining. Then a free acidity neutralization test was performed on two samples taken from the batches of oil to be refined. Another element observed was the viscosity of the oil at room temperature. Also, we observed the peroxide and saponification indices (Table 2), just for the quality of the oil, without having as much impact on the test targeted in this study, the combustion of the oil.

Table I Acid indices observed in the laboratory

\begin{tabular}{lll}
\hline Parameter & Sample I & Sample 2 \\
\hline Acid number & $\mathrm{I}_{\mathrm{a}}(\mathrm{KOH})=7,75$ & $\mathrm{I}_{\mathrm{a}}(\mathrm{KOH})=8,75$ \\
& $\mathrm{I}_{\mathrm{a}}(\mathrm{NaOH})=5,528$ & $\mathrm{I}_{\mathrm{a}}(\mathrm{NaOH})=6,25$
\end{tabular}

Table 2 Observed peroxide and saponification indices

\begin{tabular}{lll}
\hline Parameter & Sample I & Sample 2 \\
\hline Peroxide index & $\mathrm{I}=0,667$ & $\mathrm{I}=0,488$ \\
Saponification index & $\mathrm{I}=203,587$ & $\mathrm{I}=193,8$ \\
\hline
\end{tabular}

The acid number found, the 1 stneutralization test focused on $100 \mathrm{~g}$ of sample for each batch. After washings, we obtained respectively, $72.1 \mathrm{~g}$ and $75.41 \mathrm{~g}$ of neutralizeds oil.
For viscosity, with a measurement percentage of $43 \%$ and $42 \%$ respectively, at temperatures of 23 and $24^{\circ} \mathrm{C}$ and at a speed of 60 $\mathrm{rpm}$, the viscometer used indicated $236.1 \mathrm{mPa}$.s and $211.0 \mathrm{mPa} . \mathrm{s}$ respectively for samples 1 and 2 . These indices are found in the recognized range for palm oil (195-205, for the saponification index); the batches of oil considered are therefore of good quality.

\section{The transformation of oil into fuel: a "local refining"}

After the extraction of the oil, which constitutes our experimental material and the determination of its physico-chemical properties, the step that followed is that of its treatment in order to make it an acceptable fuel. The operation consists in avoiding the development of enzymes that acidify the oil and this is achieved through refining with alkali. This one started with the dilution step of the soda in water which is an exo thermic reaction.

The procedure is based on the principle that, with the acidity index equal to one, one milligram of caustic soda $(\mathrm{NaOH})$ neutralizes the free acidity contained in one gram of fatty substance. As a result, knowing the acidity indices (already found in the lab) of our raw materials, respectively 5,528 and 6.25 for the two batches of palm oil, it takes respectively 5,528 and $6.25 \mathrm{mg}$ of $\mathrm{NaOH}$ to neutralize each time $1 \mathrm{~g}$ of these oils. Hence, the neutralization of batches of 10 $\mathrm{kg}$ of each sample required the use of55.28 $\mathrm{g}$ and $62.5 \mathrm{~g}$ of $\mathrm{NaOH}$ respectively.

Then came the step of adding oil to the soda-water mixture that was put to rest for the complete dissolution of the soda. Then a homogenization of the mixture for 30 minutes. In the following, we proceeded to wash these mixtures with the water brought to a boil. A transparent container that was used for decantation. Indeed, by mixing the water (brought to a boil) with the oil already neutralized with $\mathrm{NaOH}$, are action is manifested: they are two miscible liquids. This is expressed by a clear separation of two distinct liquid phases: during settling, the still hot water precipitates with the impurities at the bottom, by difference in density of the non-miscible phases, leaving the refined oil to over swimm. In our case, the settling took place in an artisanal way, as shown in Figure 4.

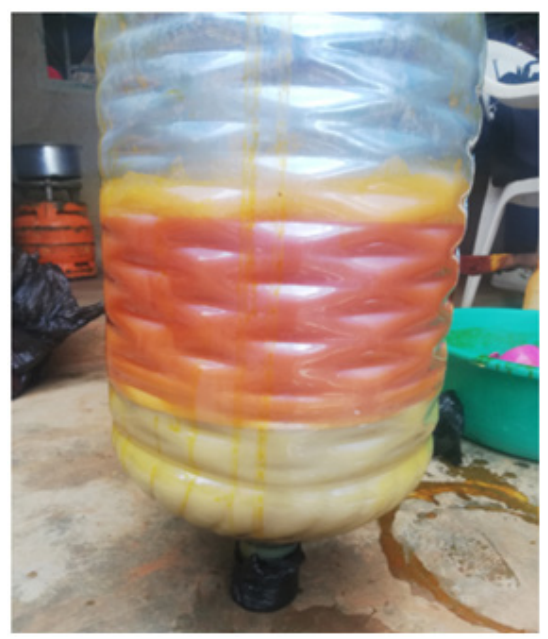

Figure 4 Separation of miscible phases by settling after neutralization: local refining.

The operation requires large quantities of water brought to a boil. Indeed, once the water and impurities well demarcated from the oil have been allowed to escape, as shown in Figure 4, the operation can be resumed, three to four times, up to the point considered satisfactory of refining. 
Eventually, the found diesel fuel is collected. At this stage, it still contains a small amount of water which must be dried by evaporation. The latter is carried out by heating, in a shallow container, bringing the oil to a temperature close to, while remaining lower, than that of boiling water. During heating, the oil being stirred by a spatula, a water vapor escapes that covers the product. The drying stops, which reflects the end of refining, when the water vapor ceases to appear above the refined oil which then takes on a shiny appearance, captivating to the eyes. However, as it cools, this oil gradually regains the dull appearance.

In the case of this experiment, at the end of the alkali refining of 20 $\mathrm{kg}$ of palm oil, taken as a raw material, we collected around $17 \mathrm{~kg}$ of refined oil, ready for use as fuel. This allows us to estimate the yield of this processing, purely artisanal, at about $85 \%$ of the starting product, a yield that seems satisfactory to us.

\section{Testing the use of refined oil as fuel}

In a trial and error approach, the stage of oil combustion in an engine had to find a volunteer who agreed to expose his machine to the test which seems an innovation, little mastered in the environment, with all the risks it entails. After having tried, in vain, among many users of the generators of the city, the Catholic University of Graben (UCG) vouched to follow the test and thus equipped us with a machine, a diesel tiller, for the test. The requirement was to find equipment to adapt the engine, that of the tiller, to the palm oil feeding system without affecting its usual feeding system.

The experiment was conducted in two stages. As if by trial and error, we first had to reassure ourselves that the device will work. So the first step was brief. After the mechanic adapted a new injection system to the engine, for 20 minutes the engine's operating rate was observed. This was not a problem; no malfunctions were observed during this test. Then, by removing the injection system used for the cause, the mechanic checked the various organs for any abnormalities that occurred during the use of palm oil. Everything came out unscathed, as in the use of diesel.

For the second stage, confirming the agro-diesel developed, it was necessary this time to insist. Without changing the engine injection system, we just bypassed the fuel system at the tank level. As for the $\mathrm{e}^{\text {st }}$ test, the engine was turned, the machine kept stationary, for lack of a tight tank to match the shaking of the tractor moving at work.

For this step, apart from examining the operation of the engine with its usual injection system, we wanted to observe the engine running for more time, up to the consumption of a liter of refined palm oil. Note that here again, despite the use of the usual engine injection system, no operating anomaly was observed; whether it's in slow motion or in full throttle. Even more interesting, this engine, whose indicated power is on average $14 \mathrm{KW}$ (between 13.2 and 14.7 $\mathrm{KW}$ indicated on its plate), finished consuming a liter of palm oil after 30 hours. This allowed us to find a first estimate of the hourly palm oil consumption of about 0.7 liters/ hour. This appears to be aclear increase, if these data are confirmed by subsequent tests, if we only compare this result with the known hourly consumption of this tiller at work, which is one litre per hour, according to the users.

In this experiment, it is important to mark the precaution taken to replace diesel with refined palm oil. This involves preheating and turning on the engine from its usual fuel system, with diesel. Then to observe the operation of the engine, the diesel being completely replaced by palm oil from a nnexe feeding device. Finally, to close, we have again returned diesel in the engine to avoid possible clogging of the sensitive organs, when the engine will come cooling.
In the particular case of the tiller used, the operationalization of the use of palm oil for the machine at work requires additional mechanical construction. The trick would be to securely attach a second combustible palm oil tank next to the engine cooling water tank and mount it easily detachable for possible washing operations in case of clogging. At the same time that this water will heat up from the engine, it will ensure the heating of the fuel oil and thus keep it very fluid.

\section{Conclusion}

At the end of this study, it turned out that the nascent industry in the Butembo region already consumes a significant amount of diesel used in high-capacity generators that require significant fuel consumption and which, in turn, induces a high cost to incur.

These large companies have not yet been sufficiently informed or sensitized on the use of agrofuels as an alternative to fossil fuels. However, because agrofuels are locally produced, their use would protect them from import costs. Moreover, the use of agro-fuels would give these companies an ecological image in the sense that their contribution to $\mathrm{CO}_{\mathrm{CO}}$ emissions is cancelled out by the renewable nature of the biomass from which they come.

However, the experience of this option in the region is still very insignificant. Only three radio stations in the region have ever experimented with the use of palm oil as biodiesel. From their experience, however, we can retain the reduction of consumption and therefore the cost related to fossil energy, energy self-dependence and the contribution to the development of rural areas by promoting and enhancing the cultivation of oil palm.

It is therefore possible to develop agro-energy with palm oil in the Butembo region. The formula: either one part for the forest, a $1 / 3 ; 1 / 3 ; 1 / 3$ second for the palm grove and a third for the other crops would make it possible to produce an HPR. However, certain conditions should first be met. First, there must be sufficient experience and technicality in the production and use of this biodiesel. Secondly, the availability of palm oil in the region must be sufficient so as not to compromise its use in human food.

Ultimately, the milestones are laid for the development of agrodiesel based on palm oil in the Butembo region. Admittedly, the estimates daring to develop proposed scenarios remain global and therefore likely to provide preliminary data. In this sense, they constitute basic hypotheses for further more specific work. This work in perspective would, among other things, refine the areas allocated to the oil palm ecological zone in the region, using geographical data taken from the country to country. It is the same for the proportions retained in the development of territories for the establishment of responsible palm groves; they remain to be refined by adapting them to specific countries.

The same precaution remains in place for the tests carried out; they remain preliminary. Here too, the prospect is to carry out more specific experiments to examine, for example, the long-term effects of the use of oil in the engine, its comparative economic advantages, as well as the comparative yields of this use. Thus, could follow the dissemination of the developed technique. While waiting for this work, the foundations of agro-diesel are laid here for the Butembo region and interested companies can already embark on the adventure by financing research work such as action work.

\section{Acknowledgments}

None. 


\section{Conflicts of interest}

The authors state that there is no conflict of interest.

\section{Funding}

None.

\section{References}

1. International Panel of Experts on Climate Change (IPCC), Climate Change 2007 Synthesis Report. IPCC Fourth Assessment Report, Geneva, Switzerland. 2007. 78 p.

2. Shanahan M, W Shubert, C Scherer, et al. Climate Change, Africa A Guide for Journalists, Rome, UNESCO, 60 p.

3. Chaibou, M. Climate change effects on beerding practices and adaptation analysis options Case of the Bouza-Niger zone. Environmental and Water Sciences. Public Health and Territorial Intelligence Journal. 2019;3(2):131-140.

4. Crehay R, D Marchal. The wood-energy sector, Gembloux, Walloon Center for Agronomic Research. Department of Rural Engineering, 2004. $119 \mathrm{p}$.

5. Janicot S, Reinert M. Climate change what challenges for the South? IRD editions. 2015.

6. ILWAC. Integrated Land and Water Management for Adaptation to Climate Variability and Change in Mali Methodological Guide Estimating Carbon Sequestration Potential in Mali,ILWAC, DGPC, AEDD and OSS, Mali. 2013.

7. De Theux B. Use of palm oil in the diesel engine, Brussels, HE Leonard de Vinci. 2004. 119 p.

8. Dorvil H. Social problems, community mediation, research and health ", Caniers Scientifique de L’ACFAS. 2010n 112291.

9. Tsalefac M. Climate Change and adaptations of peasant populations, Maison des Suds Guy Lasserre, Esplanade des Antilles. 2011. 12 p.

10. Paquet J. Bio fuels challenges and perspectives. Evolving report Analysis of the impacts of globalization on the environment in Quebec Report 8, Laboratory for studies on public policies and globalization, ENAP, Quebec. 2010;170 p.

11. Dessus B. Transport in the face of energy and climate challenges. Working paper. 2009;(86):110.

12. Houtart F. L'agro énergie. Solution for the climate or exit from the crisis for capital, Brussels/Belgium, Ed. Color of the book asb, 2009. 217 p.

13. Vyakuno K. Anthropogenic pressure and rational development of the Lubero highlands in R.D.C. Relations between societies and the physical environment in an equatorial mountain,Doctoral thesis, University of Toulouse. Le MIRAIL. 2006. 558 p.

14. Mutani M. Potentialities of agro-energy in the Butembo region case of palm oil, Butembo, T.F.C., Catholic University of Graben. 2018. 29 p.

15. Touré A Palm oil and globalization, Ouagadougou, Hamaria. 2014. 31 p.

16. Meierding E. Energy Security and Sub-Saharan Africa Graduate Institute of International and Development Studies. 2011255.

17. Meijaard E, Garcia-Ulloa J, Shei,D, et al. Oil palms and biodiversity. IUCN Working Group Report. 126 p.

18. Asiédu J. La transformation des produits agricoles en zone tropicale, paris, karthala. 1991. $335 \mathrm{p}$.

19. France, Ministère des affaires étrangères. Mémento de l'agronome, Paris, Centre de coopération Internationale en Recherches Agronomiques pour le Développement (CIRAD), CTA. 2009. 1690 p.

20. ADRIAEMS E. Oilseeds from the Belgian Congo, Bruxelles, 2nd ed. 1951. $321 \mathrm{p}$.
21. Benoit 1, Sandrine M. Calculus of emission factors Palm oil, Finalreport, CEESE-ULB, 2005. 42 p.

22. Conzelmann R. Profitability study concerning the substitution of diesel by palm oil at Palmindustrie, Ivory Coast, Berlin, GTZ, 1993. 230 p.

23. Demol J. Plant Breeding. Application to the main species cultivated in tropical regions, Presses agronomiques de Gembloux, Gembloux, Belgium. 2002. 581 p.

24. Dufour O, Olivin J. Evolution of oil palm plantation soils on savannah. Oilseeds. 1985;40(3):113-123.

25. Jacquemard JC. Oil palm, Collection Agricultures tropicales en poche, Editions Qua, CTA, Presses agronomique de Gembloux. 2011. 275 p.

26. Kambale Mirembe O. Transnational exchanges, informal networks and local development. Une étude au Nord-Est de la République démocratique du Congo, Thèse de doctorat àl'UCL. 2005. 280 p.

27. Kasay KLL. Demo-geographical dynamics and enhancement of space in an equatorial environment of altitude Case of the Nande country in Northern Kivu, Zaire, Doctoral thesis, Geography, University of Lumbubashi. 1988

28. Konan KE. How to cultivate palm oil well in Ivory Coast, National Agronomic Research Center, Palm tree sheet. 2006;n ${ }^{\circ} 14$.

29. Koppa. Recent Data on Oil Palm Cultivation (Continuation and End)", Revue de botanique appliquée et d'agriculture coloniale,8th year, bulletin. 2018; ${ }^{\circ} 82: 410-421$.

30. Leplae E. Oil palm in Africa. Its exploitation in the Belgian Congo and in the Far East,Royal Colonial Belgian Institute, Brussels, Section of Natural and Medical Sciences, Mémoires in- $8^{\circ}$. 1939VII108.

31. Libert J. Popularization of suitable and motorized equipment for oil mills and artisanal soap, Technical document, CODEART. 2011. 26 p.

32. Lussis B, Meyer S. Calculation of palm oil emission coefficients, Brussels. 2005. 42 p.

33. Marika B, J Mégrilis. Sketch for a history of the chemical society, 1857 2007. Chemical news, Brussels / Belgium. 2007. 58 p.

34. Maryment J. Precise of Phytotechnics of the main industrial crops, Brussels, IMEAC. 1960. 112 p.

35. Mattea Battaglia. "Drowned in palm oil. The explosion of global demand" Le Monde Magazine, ${ }^{\circ} 39$, supplement to the world $n^{\circ} 20336.2010 .14$ p.

36. Mirembe KO. Transnational exchanges, informal networks and local development. A study in the North-East of the Democratic Republic of the Congo, PhD thesis at UCL, 2005. 280 p.

37. Mohtadji-Lamballais C. Les aliments,Paris, Maloine. 1989. 203 p.

38. Nicolino F. Hunger, the car, the wheat and us a denunciation of biofuels, Fayard,Paris. 2007. 178 p.

39. Omont H. Contributions of palm oil production to sustainable development, Avenue, Agropolis, Montpellier. 2009. 367 p

40. Philippe L. Study on the employment-bearing sector "oil palm", ILO, Ministry of Employment and Vocational Training, Togo. 2009. 96 p.

41. Pichel RJ Some aspects of oil palm and coconut cultivation in AOF Brussels, editor. SD, 96 p.DRC, Ministry of Planning, Steering Unit Of The Prsp Process, March 2005, Monograph of the province of North Kivu (Draft 4), Ministry of Planning-DRC, Kinshasa, 1957.155 p.

42. Ronneau C. Energy, air pollution and sustainable development, LouvainLa-Neuve, DUC-UCL, Presses Universitaires de Louvain. 2004.

43. Vendreput M, RENE.The main crops in Central Africa and the Belgian Congo, INEAC, Brussels. 1956.

44. Veyret Y, J Jalta. Sustainable development. All the stakes in 12 lessons, Paris, Autrement. 2010. 240 p. 
45. Vikanza KP. Protected areas, disputed spaces and development NorthEast of R D Congo, Louvainla-Neuve, Presses Universitaires de LouvainUCL. 2011. 375 p.
46. Vikanza KP. Machining and conservation of agricultural products, CoursInédit, Faculté des Sciences Agronomiques, UCG. 2016. 414 p 